\title{
The Impact Of Merit Pay On Research Outcomes For Accounting Professors
}

\author{
Annhenrie Campbell, California State University, Stanislaus, USA \\ David H. Lindsay, California State University, Stanislaus, USA \\ Don E. Garner, California State University, Stanislaus, USA \\ Kim B. Tan, California State University, Stanislaus, USA
}

\begin{abstract}
Merit pay for professors to encourage better teaching, research and service is controversial. Its effectiveness can be examined empirically. In this study, the existence of a merit plan and ACT scores of incoming freshmen were strongly associated with measurable research outcomes. Additional study is needed to test the association with the other dimensions of faculty performance.
\end{abstract}

Keywords: merit evaluation, faculty compensation, and research productivity

\section{MOTIVATION}

An article from Inside Higher Ed, dated October 10, 2008 reads:

“. . [W] hen merit enters the picture. . . areas of agreement. . . become points of contention. . . [A]t Temple University, meanwhile, the administration is attempting to switch entirely to 'pay per performance' raises that would not take cost-of living increases or other factors into account - a change that the faculty union strenuously opposes.

'I think that the institutions are becoming more focused on outcomes and performance, partly as a result of the budgetary issues but also in response to criticisms that they are not necessarily accountable for everything that occurs,' said Kathy Hagedorn, a consultant who works with colleges on human resource issues." [Guess, 2008]. Clearly, the issue of merit pay for professors is both current and controversial.

\section{INTRODUCTION}

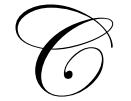

ompensation practices vary widely across colleges and universities. Periodically, the College and University Personnel Association (CUPA) surveys over 3,000 higher education institutions regarding their policies and methods for adjusting individual salaries [CUPA, 1999]. Compensation methods distinguished in the survey included: annual general wage adjustment, automatic length of service adjustment, a merit pay plan, lump sum incentive payment, bonus, gainsharing, skill- and competency based pay, team incentives, and combination across-the-board and merit pay plans. The CUPA data indicates that merit systems are used by 23.7 percent of responding institutions and plans that combine across-the-board pay raises with merit pay are used by another 26.4 percent of institutions. Since the data is aggregated, there is no way of knowing which individual schools use a merit-based or partially merit-based pay system.

Merit compensation systems for professors are intended to reward and thus encourage better faculty performance in the key areas of teaching, research and service. Such compensation systems depend on specific performance measures for operationalization. A professor's teaching performance might be measured with student evaluations or by using the outcomes assessment tests, such as the ETS Major Field tests. Research performance is usually measured by counting a professor's publications. Of the three dimensions of faculty performance usually measured -- teaching, research and service, it has proved most problematic to find an acceptable quantitative measure of service. 
Given the ongoing controversy over the usefulness of merit pay plans, we ask whether the existence of a merit-based compensation system might be an institutional determinant of faculty research output.

\section{LITERATURE REVIEW}

Increasing restrictions on public funding and a desire on the part of university administrators for greater discretion to set faculty salaries have encouraged a move away from more traditional seniority-based compensation systems [Grant, 1998]. For merit plans to be feasible, however, there must be a clear link between individual effort and performance, and that performance must be accurately measured [Heneman and Young, 1991]. Many argue adamantly that merit pay schemes are simply not practical in a university setting, because the performance of individual faculty members is too difficult or specialized to measure objectively [Johnston, 1978].

In general, merit pay is intended to provide an incentive or motivating force to push a worker, whether a laborer, a government employee, or a college professor, to greater productivity [Miller, 1979]. Merit pay for teachers is hardly a new idea; it was first used in England in the 19th Century [Holmes, 1920].

A field study of public school deans' perspectives showed that the deans do believe merit systems promote better teachers and higher quality research output, [Taylor, Lesher, Hunnicutt, Garland and Keefe, 1991]. However, this study is evidence only of opinions. We suggest that, at least in the context of an accounting program, the question of the value or effectiveness of merit pay can be addressed as an empirical issue.

This study develops empirical evidence of a relationship between merit pay and faculty research outputs -on of the three primary dimensions of faculty performance typically evaluated: teaching, research and service. If merit pay systems have the desired impact of improving faculty performance in measured areas, then schools with merit systems would be expected to boast stronger than average faculty performance in this area.

\section{HYPOTHESES}

Research output is usually measured by counting how many publications each faculty member has accumulated in a specific time period. It has been argued that the several different ways of counting publications, such as considering only those appearing in a few of the most desirable journals or those appearing in some discipline-specific bibliographic list like Cabell's Directory of Publishing Opportunities, yield similar outcomes when used as a proxy measure of research [Cabell, 2009; Feldman, 1987].

The central question of this study is then stated as:

H1: Ceteris paribus, there is a statistically significant relationship between the research output of the faculty of an accounting program and the presence or absence of a faculty merit pay plan.

A second hypothesis must be addressed as well in order to consider a potentially powerful confounding issue. It is reasonable to expect that some schools, perhaps due to reputation, would attract academically gifted students. Such attractive schools would boast not only a strong student body but also a strong faculty. Therefore, it is likely that the scholarly output of faculties of such schools, including the accounting faculty, might be stronger. The freshman ACT score was used to represent the quality of each institution's incoming student body and its relationship with a measure of faculty research output was tested in a second hypothesis:

H2: Ceteris paribus, there is a statistically significant positive association between the average ACT score of a school's incoming freshmen and the research output of the school's accounting faculty.

\section{METHODOLOGY}

The e-mail addresses of department chairs of 500 of the $800+$ accounting programs in the United States were identified using Hasselback's Accounting Faculty Directory 2003-2004. Each of the 500 chairs was e-mailed a survey using the CUPA taxonomy of methods currently used to adjust individual salary rates. The chair's response to this survey revealed whether or not a merit plan was in place at that school. A copy of the cover letter is presented as Exhibit 1. A copy of the survey instrument is presented as Exhibit 2. 
Average ACT scores were obtained from Profiles of American Colleges, 2002 published by Barron's. If the ACT score was not reported, the California State University System's Eligibility Index Table for California High School Graduates or Residents of California was used to convert the SAT score into an ACT score.

The names of individuals comprising the accounting faculty of each school were obtained from the Hasselback directory. The research output of each of these individuals was obtained from the Economic Literature Database 2002 compiled by Jean Louis Heck. The average number of publications per faculty member per school was then calculated.

A regression was then run. The dependent variable is the average number of publications per faculty member of a school. In the regression, the two independent variables are: an indicator variable assigned the value of 0 if the school does not have a merit program, and a value of 1 if it does; and the school's mean ACT score of incoming freshmen.

Therefore, the model to be tested is:

Average number of publications $=\mathrm{b} 0+\mathrm{b} 1 \mathrm{ACT}+\mathrm{b} 2 \mathrm{Merit}+\mathrm{e}$

\section{RESULTS AND CONCLUSION}

Sixty-one of the 500 surveys (12\%) were returned. Eleven of these were not usable, leaving 50 usable surveys (10\%). Only 4 types of faculty salary adjustments were reported:

- $\quad$ COLA-used by $31(62 \%)$ schools

- $\quad$ STEPS-used by $8(16 \%)$ schools

- $\quad$ Merit-used by $34(68 \%)$ schools

- $\quad$ Bonus-used by 2 (4\%) schools

Some schools used multiple methods. As seen in Table 1, correlation coefficients show that schools with merit programs tend not to offer 'time in grade' pay adjustments.

Two of the fifty schools that comprised the data set for Table 1, did not report either ACT or SAT scores. Therefore, the sample size for the regression is 48 schools.

Table 1

Pearson Correlation Coefficients

Salary Adjustment Methods Used by Accounting Programs

\begin{tabular}{lllll}
\hline & & & $\mathrm{N}=50$ & \\
& COLA & STEPS & MERIT & BONUS \\
COLA & 1.0 & & & \\
STEPS & .229 & 1.0 & & \\
& $(.109)$ & & & \\
MERIT & $<.272>$ & $<.402>* *$ & 1.0 & 1.0 \\
& $(.056)$ & $(.004)$ & & \\
BONUS & .160 & $<.089>$ & $<.079>$ & $(.587)$ \\
& $(.268)$ & $(.538)$ & $(.25)$ & \\
\hline Legend
\end{tabular}

Legend:

$\overline{\mathrm{COLA}}=$ Annual General Wage Adjustment

STEPS $=$ Automatic Length of Service Adjustment

MERIT $=$ Merit Pay Plan

$* *=$ Coefficient is significant at the .01 level 
Table 2

Descriptive Statistics

Regression Variables

$$
\mathrm{N}=48
$$

AVG PUBS

ACT

MERIT

\begin{tabular}{lcc} 
Mean & Median & Standard Deviation \\
\hline 2.59 & 1.70 & 2.79 \\
22.6 & 22.0 & 2.72 \\
0.27 & 0.00 & 0.45
\end{tabular}

Table 2 presents descriptive statistics for the regression variables. The standard deviation of average publications of 2.79 is greater than its mean value of 2.59. It should be remembered that the Economic Literature Database is somewhat selective in the journals it includes. The mean ACT score of responding school is 22.6. This is close to its median value of 22.0. Merit is a 0,1 indicator variable. Thirteen of the forty-eight schools reported using a merit system; thirty-five did not. Consequently, the mean value for Merit is 0.27 .

Correlation coefficients of the regression variables are shown in Table 3. Both the ACT variable and the Merit variable are positively and significantly correlated with Average Publications at the .001 level. However, the two independent variables are not significantly correlated with each other.

Table 3

Pearson Correlation Coefficients

Regression Variables

$$
\mathrm{N}=48
$$

\section{AVG PUBS}

ACT

MERIT

\begin{tabular}{llll} 
AVG PUBS & 1.0 & & \\
ACT & $0.479 * * *$ & 1.0 & \\
& 0.000 & & \\
MERIT & $0.564 * * *$ & 0.072 & 0.313 \\
& 0.000 & & \\
\hline
\end{tabular}

Legend:

AVG PUBS = Average publications per faculty member as listed in the Economic Literature Database

ACT $=$ Average ACT score of a school's incoming freshmen

MERIT $=$ A 0,1 indicator variable indicating a school's use of a merit pay plan

$* * *=$ Coefficient is significant at the .001 level

Table 4

Regression of Average Number of Publications

Model: Average number of publications $=\mathrm{b} 0+\mathrm{b} 1 \mathrm{ACT}+\mathrm{b} 2 \mathrm{Merit}+\mathrm{e}$

$$
\begin{aligned}
& \mathrm{N}=48 \\
& \mathrm{~F}=23.50 \\
& \mathrm{R}^{2}=0.489
\end{aligned}
$$

$\begin{array}{lll}\text { Constant } & \mathrm{b} 0= & \begin{array}{l}-8.521 * * * \\ (-3.50)\end{array} \\ & & \mathrm{b} 1= \\ \text { ACT } & \mathrm{b} 2= & \begin{array}{l}0.452 * * * \\ (4.212)\end{array} \\ & & 3.308 * * * \\ \text { Merit } & & (5.09)\end{array}$

Legend:

AVG PUBS = Average publications per faculty member as listed in the Economic Literature Database

$\mathrm{ACT}=$ Average ACT score of a school's incoming freshmen

MERIT $=$ A 0,1 indicator variable indicating a school's use of a merit pay plan

$* * *=$ Coefficient is significant at the .001 level 
Table 4 displays the results of the regression. The F statistic is 23.50 and significant at the .001 level. Therefore, it is highly unlikely that all of the regression coefficients are equal to zero. The adjusted $\mathrm{R}$ square is 0.489 , so about half of the variance of the Average Publications variable is explained by the variance of the ACT and Merit variables. The estimated coefficient on the Merit variable is 3.308 and significant at the .001 level. The estimated coefficient on the ACT variable is 0.452 and significant at the .001 level. These results are consistent with both hypotheses.

These are quite robust results indicating that there is a strong relationship between a faculty's research output and the existence of a merit system as well as a strong relationship between the quality of a the student body and faculty research output. If the only purpose of merit pay were to encourage additional research productivity, it would be easy to conclude that such systems are effective.

The minutes of a faculty discussion posted on the Drew University website in 2000 show that some faculty regard merit pay as an incentive to encourage and focus their work while others believe it is simply a means of "recognition" of work that would otherwise have been accomplished [Drew, 2000]. However faculty interpret their merit system, merit pay for faculty remains a controversial means to encourage and/or reward faculty efforts and excellence in multiple dimensions including teaching and service as well as in research.

The results developed here certainly suggest that those campuses more attractive to higher performing students, as measured by ACT scores, also seem to attract more productive faculty scholars, as measured by research output. In addition, campuses with a merit system in place clearly have faculties producing higher research outputs.

These simple tests could have been influenced by unidentified confounding factors. More to the point, additional tests are needed to determine whether merit pay systems are also associated with better outcomes for the other dimensions of rewarded faculty performance: teaching and service. Both faculty and administrators need to continue to examine the design and implementation of merit systems.

\section{AUTHOR INFORMATION}

Annhenrie Campbell, Ph.D., CPA, CMA, CGFM is a Professor of Accounting at California State University, Stanislaus. She holds a Ph.D. from the University of Colorado in Boulder. Her research interests include the impact of faculty research on students' professional preparation and academic success. She teaches advanced financial accounting and governmental accounting courses.

Don E. Garner, Ph.D., CPA, CIA is professor and former chair of the Department of Accounting in the College of Business Administration at California State University, Stanislaus, where he specializes in the area of auditing and accounting. He is a certified public accountant and a certified internal auditor. He has coauthored a number of monographs on the practice of accounting internationally and in specific locales including the Pacific Basic and the Islamic Middle East.

David H. Lindsay, Ph.D., CPA (inactive), CISA, CFE is a Professor of Accounting and the Chair of the Department of Accounting and Finance at California State University, Stanislaus. His Ph.D. is from the Graduate School of Management at Kent State University. His research interests include determinants of CPA Exam pass rates, the impact of merit programs on research and teaching outcomes, fraud detection, and various AACSB related issues. He teaches Intermediate Accounting I and II.

Kim Tan, Ph.D., CA is a Professor at California State University Stanislaus. Her Ph.D. in Business Administration is from Temple University in Philadelphia. She's a Chartered Accountant with the New Zealand Society of Accountants and a member of the Australian Computer Society. She is interested in pedagogical and behavioral research using experimental, archival and survey data. She mainly teaches Cost and Managerial Accounting. 


\section{REFERENCES}

1. Cabell. Cabell's Directories of Publishing Opportunities (site license and hard copy), Beaumont TX: Cabell Publishing Company.

2. CUPA: College and University Personnel Association [1999] Survey of Compensation Practices in Higher Education. Washington, D.C., p. 17.

3. Drew University, Some Thoughts on our Merit Pay Discussions. AAUP Online, 6/8/00 retrieved 11/22/09 from http://www.depts.drew.edu/aaup/merit.htm.

4. Feldman, K.A., Research Productivity and Scholarly Accomplishment of College Teachers as Related to Their Instructional Effectiveness: A Review and Exploration. Research in Higher Education. Volume26, Number 3, pp. 227-298.

5. Grant, Hugh [1998] Academic contests? Merit Pay in Canadian Universities. Relations Industrielles. Quebec. Volume. 53, Number. 4, pp. 647-667.

6. Guess, Andy [2008] Debating the Merits of Merit Pay. Inside Higher Ed. retrieved 11/22/09 from http://www.insidehighered.com/news/2008/10/10/merit.

7. Heneman, Herbert G. and I. Phillip Young [1991] Assessment of a Merit Pay Program for School District Administrators. Public Personnel Management. Volume 20, Number 1, pp. 35-48.

8. Holmes, E. G. A. [1920] In Quest of an Ideal. London: Cobden-Sanderson, p. 62.

9. Johnston, James J. [1978] Merit Pay for College Faculty? Advanced Management Journal. Volume 43, Number 2, p. 44.

10. Miller, Ernest C. [1979] Pay for Performance. Personnel. Volume 56, Number 4, p. 4.

11. Taylor, Ruth Lesher, Garland G. Hunnicutt, and J. Michael Keeffe [1991] Merit Pay in Academia: Historical Perspectives and Contemporary Perceptions. Review of Public Personnel Administration, Volume 11, Number 3, pp. 51-65. 


\section{EXHIBIT 1}

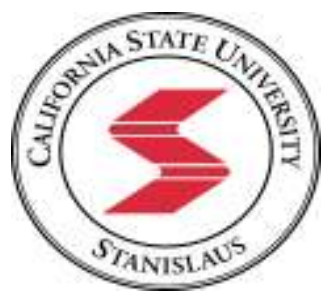

\section{COLLEGE OF BUSINESS ADMINISTRATION}

California State University, Stanislaus

Department of Accounting and Finance

801 West Monte Vista Avenue • Turlock, California 95382

Phone (209) 667-3671 • Fax (209) 667-3042

December 26, 2002

Dear Department Chair:

My colleagues, Dr. Annhenrie Campbell and Dr. Kim B. Tan, and I are asking you to take a few minutes to complete the attached survey for our research study on methods used to adjust individual faculty salaries.

The survey will take you just a few minutes to complete. Please return, via e-mail, your completed questionnaire-no matter how few questions you answer.

Your responses will be pooled with others for statistical analysis. No specific individual response will be discussed or disclosed.

Your participation is completely voluntary. While you may choose to disregard this request, we hope you decide to participate in our study.

Please contact me with any questions or concerns you may have regarding this project.

Best regards,

David H. Lindsay, Ph.D., CPA

Professor of Accounting

Phone: (209) 667-3296

E-mail: Acc_Dept_Chair@csustan.edu 


\section{EXHIBIT 2}

This is a survey of the methods used to arrive at individual faculty salary amounts in accounting programs. Please check all items applicable to your department's procedures in the years 1997, 2000, and 2002.

\begin{tabular}{|c|c|c|c|}
\hline & 1997 & 2000 & 2002 \\
\hline Annual General Wage Adjustment & [ ] & [ ] & [ ] \\
\hline Automatic Length of Service Adjustment & [ ] & [ ] & [ ] \\
\hline Merit Pay Plan & [ ] & [ ] & [ ] \\
\hline Lump Sum Incentive Payment & [ ] & [ ] & [ ] \\
\hline Combination Across-the-Board And Merit Pay Plan & [ ] & [ ] & [ ] \\
\hline Bonus & [ ] & [ ] & [ ] \\
\hline Gainsharing & [ ] & [ ] & [ ] \\
\hline Skill- and Competency Based Pay & [ ] & [ ] & [ ] \\
\hline Team Incentives & [ ] & [ ] & [ ] \\
\hline Other & [ ] & [ ] & [ ] \\
\hline
\end{tabular}

Please forward, via e-mail, the completed survey to Acc_Dept_Chair@csustan.edu 